\title{
Structural Stability and Accumulation of Organic Matter in Some Soils under Cashew Tree Orchards in the Department of Touba in North-West Côte d'Ivoire
}

\author{
Alui Konan Alphonse1* ${ }^{*}$, Ballo Koffi Celestin², Kouassi Kouakou Joselin'1, Yao-Kouamé Albert ${ }^{3}$ \\ ${ }^{1}$ UFR of Biological Sciences, Geosciences Department, Pedagogical and Research Unit (UPR) of Agro-Pedology, Peleforo \\ University Gon Coulibaly, Korhogo, Côte d'Ivoire \\ ${ }^{2}$ National Center for Agronomic Research, Abidjan, Côte d'Ivoire \\ ${ }^{3}$ UFR of Earth Sciences and Mining Resources, Department of Soil Sciences, Felix Houphoüet-Boigny University, \\ Abidjan, Côte d'Ivoire \\ Email: *aluialphonse@gmail.com
}

How to cite this paper: Alphonse, A.K., Celestin, B.K., Joselin, K.K. and Albert, Y.-K. (2020) Structural Stability and Accumulation of Organic Matter in Some Soils under Cashew Tree Orchards in the Department of Touba in North-West Côte d'Ivoire. Open Journal of Soil Science, 10, 181-193. https://doi.org/10.4236/ojss.2020.105009

Received: April 17, 2020

Accepted: May 10, 2020

Published: May 13, 2020

Copyright $\odot 2020$ by author(s) and Scientific Research Publishing Inc. This work is licensed under the Creative Commons Attribution International License (CC BY 4.0).

http://creativecommons.org/licenses/by/4.0/

\begin{abstract}
Degradation of the physical quality of the soil is a common problem encountered in agrosystems, particularly in the case of open field cropping systems in the northern areas of Côte d'Ivoire. Thus, the structural stability of the soil, which is a good indicator of the sensitivity to threshing and to water erosion in relation to the accumulation of organic matter, was evaluated in two types of soil (Ferralsol and Cambisol) in cashew orchards, in two villages (Mahana and Sanankoro) producing cashew nuts, located the Department of Touba in the North West of Côte d'Ivoire. The objective of this study is to develop new technical routes that are better suited to further promote the sequestration of organic carbon in the soil. Soil samples were taken from open soil profiles at the two chosen sites to allow laboratory analyzes. The results indicate that the surface horizon of Cambisol (site 1) is more stable (Is $=0.78$ ) than that of Ferralsol (site 2; Is $=1.08$ ) with nevertheless relatively small thicknesses of horizons. The median horizons and those of depth, indicate a mediocre stability (Is vary from 1.03 to 1.62). In terms of the quantity of organic carbon, the estimated values vary from 1.96 to $4.53 \mathrm{t} \cdot \mathrm{ha}^{-1}$ for Cambisol (site 1) and from 1.44 to $3.46 \mathrm{t}^{-\mathrm{ha}^{-1}}$ for Ferralsol (site 2). These values remain relatively low especially at the level of the median horizons and those located in depths. Statistical tests have shown a very highly significant and negative association between the structural stability of soils and the amount of organic carbon in the different horizons. The relationship implies that organic carbon plays an important role in the structural stability of soil horizons under cashew tree orchards.
\end{abstract}




\section{Keywords}

Structural Stability, Organic Carbon, Soils, Cashew, Côte d'Ivoire

\section{Introduction}

The cashew tree was introduced in Côte d'Ivoire in 1951. It was only from 1959-1960 that a forest plantation installation program was implemented by Technical Assistance Society for the Modernization of Agriculture in Côte d'Ivoire (SATMACI) and Forest Development Society (SODEFOR). These plantations were set up for ecological purposes in order to fight against the advancement of the desert and soil degradation [1]. The plant plays an important role today both socially and economically. The sector employs nearly 250,000 producers and directly or indirectly provides livelihoods for approximately 1.5 million people [2]. The cashew tree, a sturdy, drought-tolerant tree, helps to restore the forest shade in the northern part of the Ivory Coast. The plant is a tool for an ecological and social transition. In two decades, the country has taken the place of the world's leading producer of cashew nuts. From 8500 tonnes in 1989, Ivorian cashew production exceeded 70,000 tonnes in 1999, then 350,000 tonnes in 2010. Despite the drought in 2016 and clandestine sales to neighboring countries, the threshold of 700,000 tonnes was officially crossed in 2017 [2] [3]. Today, the cashew nut tree is experiencing an extraordinary craze among the populations to the point of monopolizing the best land and large areas. It is therefore important to take a look at the properties of the soil under the cashew orchards, a culture that crystallizes the hopes and expectations of peasants who have been in poverty for so long.

Indeed, the physical state of agricultural soil is one of the pillars that underpin its productive capacity [4]. Agricultural soil is a structure constructed from aggregates of different sizes which result from the assembly of organic and mineral particles. These aggregates provide a pore space between them which plays a decisive role in the circulation of water and air, even the storage and availability of nutrients [5]. The structure of a soil is one of its essential physical properties, conditioning the exchange of air, water and energy between the soil and the atmosphere. It therefore constitutes an essential criterion in determining cultural aptitudes. The stability of the structure is considered to be a good indicator of the quality of the soils and their sensitivity to runoff and erosion [6]. It is the most studied physical parameter in experiments comparing no-till to plowing [7]. Intensive tillage destroys the cohesion of aggregates and weakens the structure, while direct seeding helps restore soil aggregation and improve its structural stability [8]. In this study, we propose to assess the level of structural stability in relation to the accumulation of organic matter, of two (2) types of soil under cashew orchards in the department of Touba in the north-west of the Côte d'Ivoire, with a view to building new technical routes, thus further promoting 
the sequestration of organic carbon in the soil while ratifying the sink function towards greenhouse gases.

\section{Material and Methods}

\subsection{Material}

\subsubsection{Presentation of the Study Area}

The area of interest is the department of Touba, specifically the villages of Mahana (Site 1) and Sanankoro (Site 2), located in the northwest of Côte d'Ivoire (Figure 1). It is subject to a tropical transition climate, characterized by an average rainfall of $1500 \mathrm{~mm} \cdot \mathrm{year}^{-1}$. The relief is formed by plateaus, of average altitude equal to $550 \mathrm{~m}$. Some isolated mountains culminate between 600 and 750 $\mathrm{m}$ and present models with massive forms, with convex vertices and with steep sides. The hydrographic network is very varied (parallel, dendritic and lattice types). This region belongs to the Archean domain of the Man Ridge where the geological formations (gneiss para and ortho-derivatives, charnockites, migmatites, quartzites) have been influenced by the Leonian and Liberian orogenic megacycles [9].

\subsubsection{Natural Environment Material}

In order to characterize the material in the natural environment, soil samples were taken from open soil profiles at the different sites chosen for the study in order to allow laboratory analyzes.

\subsection{Methods}

\subsubsection{Morpho-Pedological Characterization of the Soils of the Study Sites}

A morpho-pedological characterization of the soils under 11 cashew orchards

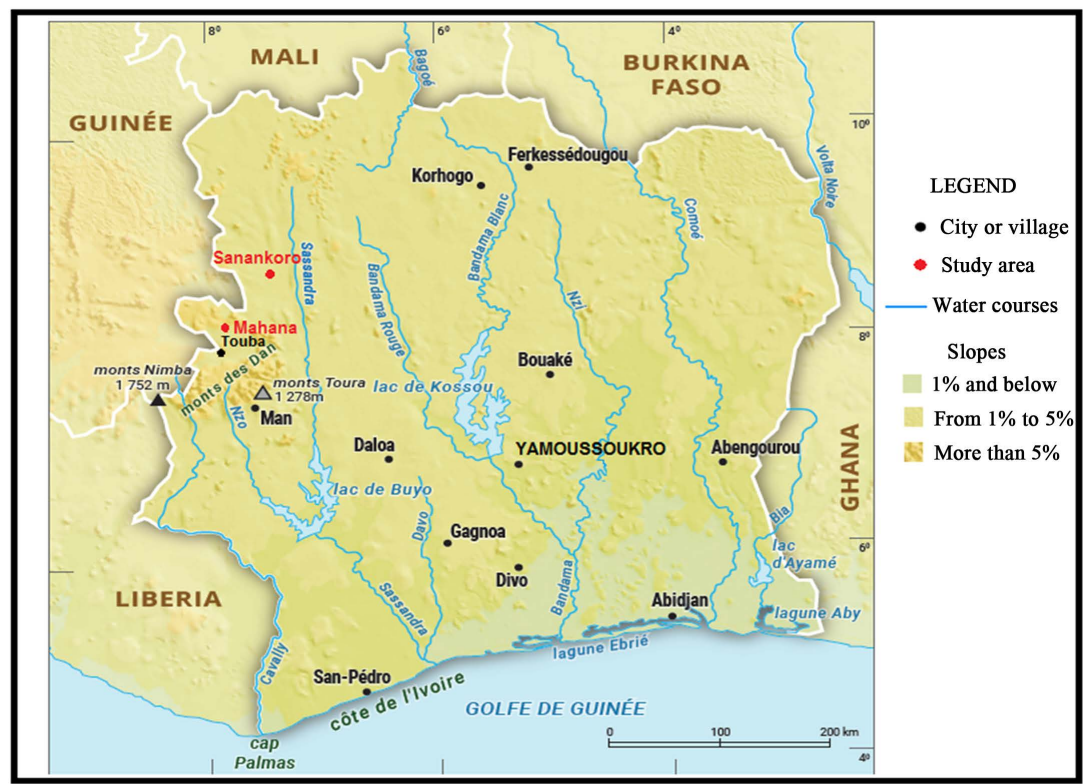

Figure 1. Geographical situation of the study area. 
whose ages vary from 6 to 12 years was carried out using open soil profiles on toposequences implanted in a well chosen azimuthal direction. In the village of Mahana, a total of 4 cashew tree orchards against 5 in Sanankoro were investigated. The trees were heterogeneous in size. Composite soil samples were taken, from depths, $0-20 \mathrm{~cm} ; 20-40 \mathrm{~cm}$; and $40-60 \mathrm{~cm}$, in open pits considering two (02) topographic levels (upper slope and mid slope). The total number of pits is 2 per site, making a total of 22 pits for the study. The soil samples taken were described in the sun, taking care to indicate on the description sheet, the date, the place, the map sheet, the vegetation, the local slope, the topographic position, and the microrelief.

\subsubsection{Laboratory Analysis of Soil Samples}

Physical soil analyzes of the grain size and the apparent density of the soil were carried out. In terms of chemical and physico-chemical analyzes, the soil $\mathrm{pH}$ was measured according to standardized methods (AFNOR NF ISO 10-390, 2005) and organic carbon by the method of [10]. The evaluation of the quantity of organic carbon (q) in each horizon (i) was calculated according to the following formula [11]:

$$
\mathrm{q}(\mathrm{i})=0.1 \times \mathrm{Ei} \times \mathrm{da}(\mathrm{i}) \times \mathrm{Ci}
$$

where:

- $\mathrm{q}(\mathrm{i})$ : content in Corganic, in the soil horizon (i) $\left(\mathrm{t} \cdot \mathrm{ha}^{-1}\right)$,

- Ei: thickness of the horizon (i) $(\mathrm{cm})$,

- da(i): apparent density of the fine fraction $(<2 \mathrm{~mm})$ in the horizon (i) $\left(\mathrm{g} \cdot \mathrm{cm}^{-3}\right)$,

- Ci: concentration of organic carbon in fine earth for the horizon (i) $\left(\mathrm{g} \cdot \mathrm{kg}^{-1}\right)$.

The total quantity of carbon $(\mathrm{Q})$ in the soil up to a selected depth is the sum of the quantities in each horizon:

$$
\mathrm{Q}=\Sigma(\mathrm{q}(\mathrm{i}))
$$

Structural water stability is determined by the [12] method. Four grams of the fraction ( 1 - 2) mm obtained during dry sieving (dry stability) are deposited in a sieve $(70 \mu \mathrm{m})$ animated with an alternating movement and immersed in a beaker containing $100 \mathrm{ml}$ of distilled water for 3 minutes. The unstable aggregates in water are in suspension in the beaker, their mass is weighed after drying in an oven for 24 hours. The weighed mass corresponds to the mass of the unstable aggregates in water (MAI in $\mathrm{g}$ ). The sieve containing the remaining aggregates, plant debris and sand particles is again animated with a vertical reciprocating movement in a beaker containing $100 \mathrm{ml}$ of a solution of sodium hexametaphosphate ( $2 \mathrm{~g} / \mathrm{l})$ up to complete dispersion (about 30 minutes). The particles in suspension in the solution correspond to the water-stable aggregates and their mass (MAS) is determined after passing through the oven for 24 hours at $105^{\circ} \mathrm{C}$. The mass of sand retained in the sieve is subtracted from the total mass (4 g). Knowing the mass of stable aggregates and unstable aggregates in water, the water stability index (IS) is defined as follows: 


$$
\mathrm{IS}=[\mathrm{MAS} /(\mathrm{MAS}+\mathrm{MAI}-\mathrm{MC})] * 100
$$

MAS: mass of water-stable aggregates ( $\mathrm{g}$ )

MAY: mass of aggregates unstable with water $(\mathrm{g})$

MC: mass of sodium hexametaphosphate or calgon used (g).

\subsubsection{Statistical Processing of the Data Collected}

The results of the observations and measurements were analyzed using SPSS version 20 software. An analysis of variance was first performed. Then, the means were separated by the TUKEY test at the threshold of $5 \%$ when the effects were significant. The normality of the data and the homogeneity of the variances were checked beforehand using the de, Kolmogorov-Smirnov and Shapiro-Wilk test, respectively.

\section{Results}

\subsection{Morphological Characteristics of the Different Soils of the Study Sites}

The soils observed and described at the Mahana site are for the most part deep (reaching $120 \mathrm{~cm}$ ), having a humiferous, humid penetration, with numerous decimetric to centimetric roots in sub-horizontal orientation, at the level of the surface horizons. The texture is predominantly sandy-clay-silty, with around $20 \%$ to $25 \%$ clay at the surface horizon. The horizons, median and depth have a predominantly clay-sandy-silty texture. Medium to low porosity is observed (Figure 2). There is a good inking of the roots of the plants at the level of the profile. For the most part in the CPCS classification, a rejuvenated and reworked browned soil whose conversion into the WRB classification gives an "Eutric Cambisol" in the WRB classification.

The small variation and the state of the vegetation of the site of Sanankoro, allowed us to have only one type of soil. Thus, under the orchards of cashew trees, the soils observed and described are deep (reaching $120 \mathrm{~cm}$ ). A humiferous penetration is observed on the surface and at medium depth of the profile. The soil is moist, with numerous decimetric to centimetric roots in a sub-horizontal orientation, at the level of the surface horizons. The texture is predominantly sandy-clay-silty, with around $12 \%$ to $15 \%$ clay at the surface horizon. The horizons, median and depth have a predominantly clay-sandy-silty texture. Good porosity is observed. There is a good inking of the roots of the plants at the level of the profile. For the most part, this is a CPCS classification of a ferralitic soil, a "Plinthic Ferralsol", in the WRB classification (Figure 2).

\subsection{Physical and Physico-Chemical Parameters Evaluated at the Different Study Sites}

\subsubsection{Granulometry, Total Porosity and Structural Stability Index of Different Soils}

Table 1 reports the average values of some physical parameters characterizing the different soil horizons as a function of depth (Figure 3). Thus, the clay content 


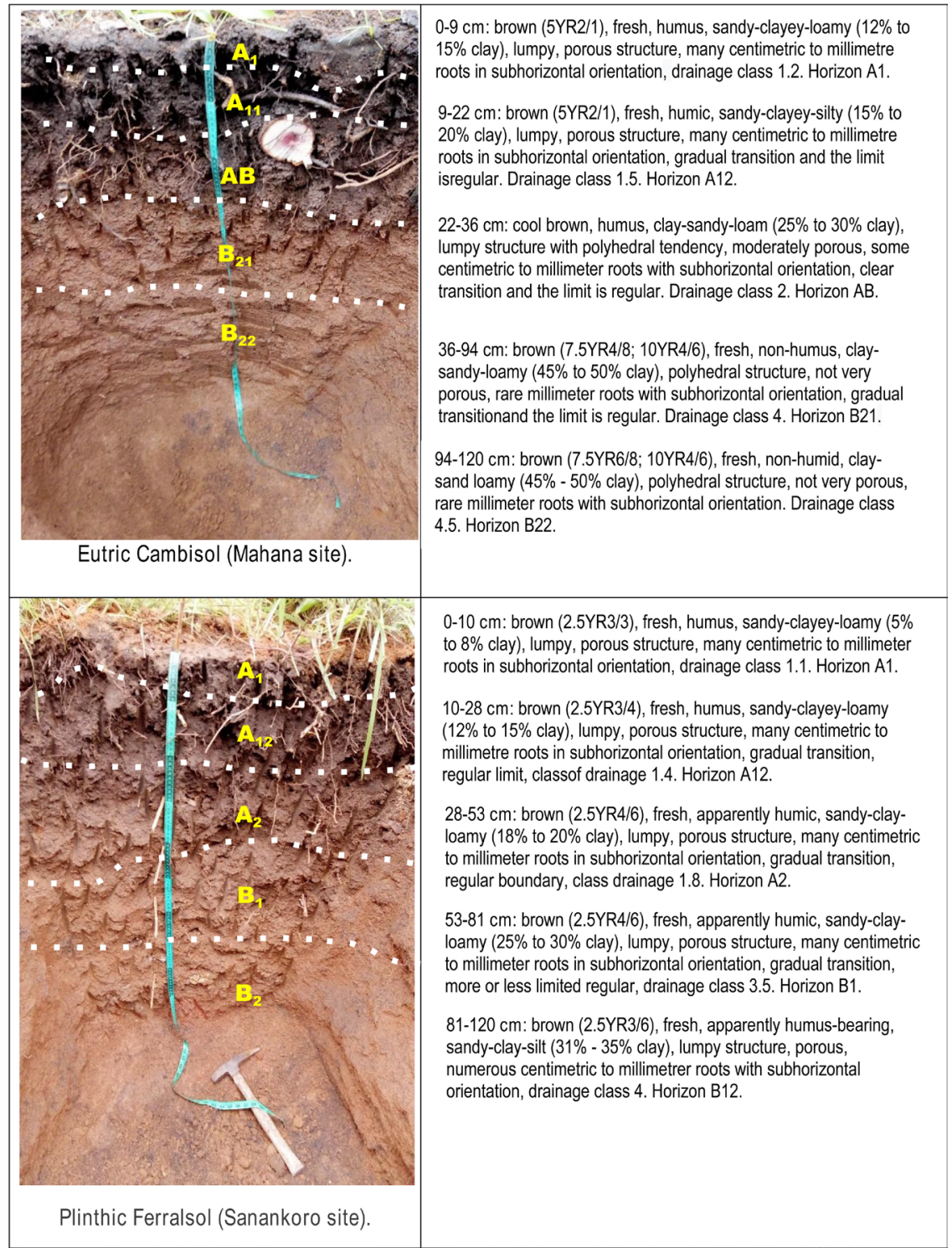

Figure 2. Types of soils encountered at the different study sites.

(A) of the soil increases from the surface to the depth whatever the type of soil. Values; 15.12 to $36.50 \mathrm{~g} \cdot \mathrm{kg}^{-1}$ for site 1 of Mahana and 25.48 and $32.70 \mathrm{~g} \cdot \mathrm{kg}^{-1}$ for site 2 of Sanankoro show no significant difference (Fcal $=0.81$; Pcal $\geq 0.05$ ) based on statistical analyzes. The silt content (fine and coarse) is low regardless of the depth of the soil. These contents do not exceed $8 \mathrm{~g} \cdot \mathrm{kg}^{-1}$, there are no significant differences between the contents evaluated whatever the depth and the types of soil $\left(\chi^{2}=1.28\right.$; Pcal $\left.\geq 0.05\right)$. A significant difference is noted in the coarse silt (Lg). The content increases with depth at site $2\left(5.34\right.$ to $\left.6.13 \mathrm{~g} \cdot \mathrm{kg}^{-1}\right)$, while on the contrary it decreases at site 1 , with the contents varying from 3.88 at $5.40 \mathrm{~g} \cdot \mathrm{kg}^{-1}\left(\chi^{2}=5.98^{*}\right.$; Pcal $\left.\leq 0.05\right)$. The data analyzed in terms of sand content do not contain any significant differences. They vary from 13.03 to 25.11 $\mathrm{g} \cdot \mathrm{kg}^{-1}$ at the level of fine sand (Sf; $\chi^{2}=0.95 ; \mathrm{Pcal} \geq 0.05$ ); and from 35.59 to 46.65 $\mathrm{g} \cdot \mathrm{kg}^{-1}$ for coarse sand (Sg; $\chi^{2}=0.98$; Pcal $\geq 0.05$ ). 


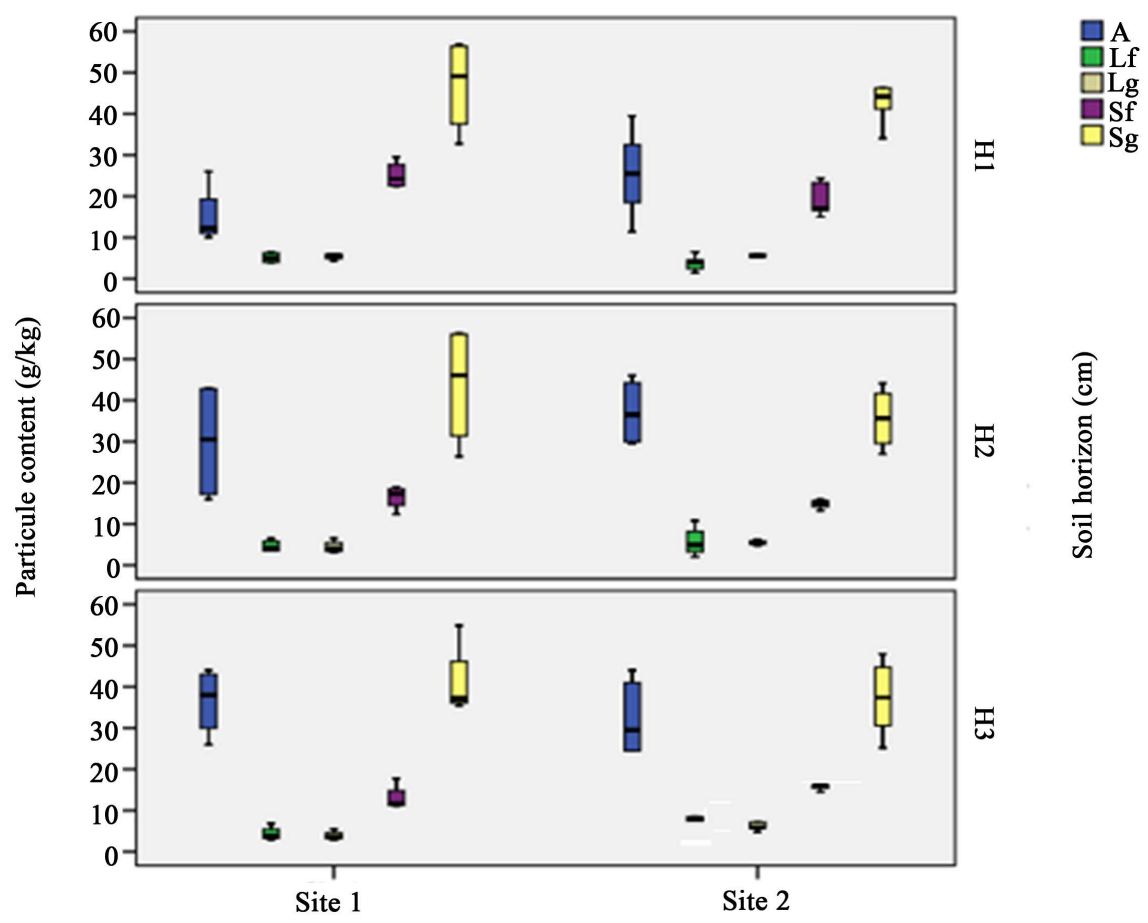

Study sites

Figure 3. Evolution of the granulometry on the different study sites. A = Clay; Lf = fine silt; $\mathrm{Lg}=$ coarse silt; $\mathrm{Sf}=$ Fine sand; $\mathrm{Sg}=$ Coarse sand $\mathrm{H}=$ horizon.

Table 1. Physical and physico-chemical parameters of the different study sites.

\begin{tabular}{|c|c|c|c|c|c|c|c|c|c|c|}
\hline \multirow{2}{*}{ Sites } & \multirow{2}{*}{$\begin{array}{l}\text { Horizons } \\
(\mathrm{cm})\end{array}$} & \multicolumn{5}{|c|}{ Granulometry $\left(\mathrm{g} \cdot \mathrm{kg}^{-1}\right)$} & \multirow{2}{*}{$\begin{array}{c}\text { Total } \\
\text { Porosity; } \\
\text { Pt (\%) }\end{array}$} & \multirow{2}{*}{$\begin{array}{c}\text { Indice de } \\
\text { stabilité } \\
\text { structurale; } \\
\text { Is }\end{array}$} & \multirow{2}{*}{$\mathrm{pH}$ eau } & \multirow{2}{*}{$\begin{array}{c}\text { Quantité } \\
\text { de carbone } \\
\text { organique; } Q \\
\left(t \cdot h a^{-1}\right)\end{array}$} \\
\hline & & A & Lf & $\mathrm{Lg}$ & Sf & $\mathrm{Sg}$ & & & & \\
\hline \multirow{3}{*}{ 茎 } & $\begin{array}{c}\mathrm{H} 1 \\
(0-20)\end{array}$ & $15.12 \pm 7.33 \mathrm{a}$ & $5.12 \pm 1.31 \mathrm{a}$ & $5.4 \pm 0.71 \mathrm{a}$ & $25.11 \pm 3.32 \mathrm{a}$ & $46.95 \pm 11.5 \mathrm{a}$ & $68.58 \pm 2.4 \mathrm{ab}$ & $0.78 \pm 0.29 \mathrm{a}$ & $6.5 \pm 0.5 \mathrm{a}$ & $4.53 \pm 2.84 \mathrm{a}$ \\
\hline & $\begin{array}{c}\mathrm{H} 2 \\
(20-40)\end{array}$ & $30 \pm 14.76 \mathrm{a}$ & $4.63 \pm 1.44 \mathrm{a}$ & $4.4 \pm 1.49 \mathrm{~b}$ & $16.51 \pm 2.9 \mathrm{a}$ & $43.72 \pm 14.7 \mathrm{a}$ & $58.40 \pm 6.22 \mathrm{~b}$ & $1.45 \pm 0.14 \mathrm{a}$ & $6 \pm 0.3 \mathrm{a}$ & $1.96 \pm 0.12 \mathrm{a}$ \\
\hline & $\begin{array}{c}\text { H3 } \\
(40-60)\end{array}$ & $36.50 \pm 8.23 \mathrm{a}$ & $4.33 \pm 1.70 \mathrm{a}$ & $3.88 \pm 1.11 \mathrm{~b}$ & $13.03 \pm 3.16 \mathrm{a}$ & $41.14 \pm 9.1 \mathrm{a}$ & $42.26 \pm 2.11 \mathrm{c}$ & $1.40 \pm 0.33 \mathrm{a}$ & $6.2 \pm 0.5 \mathrm{a}$ & $1.96 \pm 0.14 \mathrm{a}$ \\
\hline \multirow{3}{*}{ 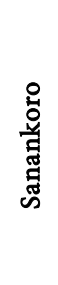 } & $\begin{array}{c}\mathrm{H} 1 \\
(0-20)\end{array}$ & $25.48 \pm 11.1 \mathrm{a}$ & $3.80 \pm 1.92 \mathrm{a}$ & $5.34 \pm 0.35 \mathrm{a}$ & $19.30 \pm 4.24 \mathrm{a}$ & $44.15 \pm 7.6 \mathrm{a}$ & $72.83 \pm 11.89 \mathrm{a}$ & $1.03 \pm 0.28 \mathrm{a}$ & $5.8 \pm 0.8 \mathrm{~b}$ & $3.46 \pm 0.37 \mathrm{a}$ \\
\hline & $\begin{array}{c}\mathrm{H} 2 \\
(20-40)\end{array}$ & $37.12 \pm 8.36 \mathrm{a}$ & $5.69 \pm 3.71 \mathrm{a}$ & $5.50 \pm 0.60 \mathrm{a}$ & $14.89 \pm 1.14 \mathrm{a}$ & $35.6 \pm 7.5 \mathrm{a}$ & $72.84 \pm 6.54 \mathrm{a}$ & $1.37 \pm 0.16 \mathrm{a}$ & $5.5 \pm 0.5 b$ & $2.08 \pm 1.15 \mathrm{a}$ \\
\hline & $\begin{array}{c}\mathrm{H} 3 \\
(40-60)\end{array}$ & $32.70 \pm 9.24 \mathrm{a}$ & $7.37 \pm 1.61 \mathrm{a}$ & $6.13 \pm 0.1 \mathrm{a}$ & $16.07 \pm 1.42 \mathrm{a}$ & $37.2 \pm 9.5 \mathrm{a}$ & $54.28 \pm 2.33 \mathrm{~b}$ & $1.62 \pm 0.07 \mathrm{a}$ & $5.4 \pm 0.5 \mathrm{~b}$ & $1.44 \pm 0.54 \mathrm{a}$ \\
\hline \multirow{3}{*}{\multicolumn{2}{|c|}{$\begin{array}{l}\text { Associated } \\
\text { statistical } \\
\text { tests }\end{array}$}} & $\mathrm{Fcal}=0.811 \mathrm{~ns}$ & $\chi^{2}=1.283 \mathrm{~ns}$ & $\chi^{2}=5.98^{*}$ & $\not 2=0.955 \mathrm{~ns}$ & $\chi^{2}=0.956 \mathrm{~ns}$ & $x^{2}=3.82^{*}$ & $\mathrm{Fcal}=0.828 \mathrm{~ns}$ & $\mathrm{Fcal}=9.29^{\star}$ & $\mathrm{Fcal}=0.61 \mathrm{~ns}$ \\
\hline & & $\mathrm{Pcal}=0.377$ & Pcal $=0.257$ & Pcal $=0.014$ & $\mathrm{Pcal}=0.328$ & Pcal $=0.329$ & $\mathrm{Pcal}=0.045$ & $\mathrm{Pcal}=0.372$ & Pcal $=0.006$ & Pcal $=0.44$ \\
\hline & & Pthéor $\geq 0.05$ & Pthéor $\geq 0.05$ & Pthéor $\leq 0.05$ & Pthéor $\geq 0.05$ & Pthéor $\geq 0.06$ & Pthéor $\leq 0.05$ & Pthéor $\geq 0.05$ & Pthéor $\leq 0.05$ & Pthéor $\geq 0.05$ \\
\hline
\end{tabular}

The means followed by the same letter in the same column. Are not significantly different at the probability threshold $<0.05$, according to the TUKEY test, $\chi^{2}=\mathrm{Chi}^{2}$, Kruskal-Walis test, $\mathrm{F}=\mathrm{F}$ of Ficher (ANOVA), $\mathrm{Pr}$ cal $=$ Calculated probability, ${ }^{*}=$ significant, $\mathrm{ns}=$ not significant. $\mathrm{A}=\mathrm{Clay} ; \mathrm{Lf}=$ fine silt; $\mathrm{Lg}=$ coarse silt; Sf = Fine sand; $\mathrm{Sg}$ = coarse sand; $\mathrm{Q}=$ Quantity of organic carbon; Is = Structural stability index, $\mathrm{Pt}=$ Total porosity. 
The total porosity evaluated in the soils of the different sites contains a significant difference between the values noted (Pt; $\left.\chi^{2}=0.32^{*} ; \mathrm{Pcal} \leq 0.05\right)$. The soil of site $2(54.28 \%$ to $72.83 \%)$ is more porous than that of site 1 ( $42.26 \%$ to $68.58 \%)$. It should be noted that, in general, the porosity decreases as a function of the depth of the soil whatever the site.

The stability index evaluated (Table 1 ) at the different sites does not show any significant difference (Is; Fcal $=0.82 ; \mathrm{Pcal} \geq 0.05$ ). The surface horizon of site 1 (Is $=0.78$ ) is more stable than that of site 2 (Is $=1.08$ ). However, the thickness of the surface horizon is small. At the level of the median horizons and at depth, the stability is poor (Is vary from 1.03 to 1.62; Figure 4).

\subsubsection{Acidity and Amount of Organic Carbon in Different Soils}

The $\mathrm{pH}$ of the soil, translates the acidity and ranges from 1 to 14 . It provides information on the nature of the rocks on which not only the soil was formed, but also the activity of microorganisms. Thus, the soil of site 1 (6 to 6.5) is weakly acidic as long as that of site 2 is strongly to moderately acidic (5.4 to 5.8). There is a significant difference between the values recorded ( $\mathrm{pH}$; Fcal $=9.29^{\star}$; Pcal $\leq$ 0.01 ). The amount of organic carbon evaluated from the point of view of vertical dynamics, does not differ from one site to another (Q; Fcal = 0.61; Pcal $\geq 0.05$ ). Estimated values vary from 1.96 to $4.53 \mathrm{t} \cdot \mathrm{ha}^{-1}$ for site 1 and from 1.44 to 3.46 $\mathrm{t} \cdot \mathrm{a}^{-1}$ for site 2 . Whatever the site, the surface horizons are more provided with carbon.

\subsection{Relationship between Stocks of Organic Matter, Acidity and Physical Characteristics, of the Soils Investigated}

The various correlation tests carried out between organic carbon stocks, acidity, structural stability index, total porosity and particle size distribution of the soils gave several levels of significance (Table 2). Thus, at site 1, the most significant

Table 2. Correlation between the different soils parameters.

\begin{tabular}{ccccccc}
\hline \multirow{2}{*}{ study sites } & $\begin{array}{c}\text { variable } \\
\text { couple }\end{array}$ & $\begin{array}{c}\text { Correlation } \\
\text { coefficient } \mathbf{r}\end{array}$ & $\mathbf{r}^{2}$ & $\mathbf{t}$ & $(\mathrm{Pr}>|\mathbf{t}|)$ & Significance \\
\hline & Q-pH & 0.72 & 0.51 & 3.366 & 0.007 & $* *$ \\
& Q-Is & 0.72 & 0.51 & -3.966 & 0.003 & $* *$ \\
Mahana (Site 1) & Q-Sf & 0.74 & 0.54 & 3.522 & 0.006 & $* *$ \\
& Is-pH & -0.56 & 0.31 & -2.146 & 0.048 & $*$ \\
& Is-Sf & -0.76 & 0.57 & -3.741 & 0.004 & $* *$ \\
& Sf-pH & 0.61 & 0.37 & 2.640 & 0.025 & $*$ \\
& Sf-Pt & 0.81 & 0.65 & 4.367 & 0.001 & $*$ \\
& Q-Lf & -0.76 & 0.57 & -4.155 & 0.001 & $* *$ \\
Sanankoro (Site 2) & Q-Is & -0.78 & 0.60 & -4.408 & 0.001 & $* *$ \\
& Lf-Is & 0.70 & 0.49 & 3.360 & 0.006 & $* *$ \\
& A-pH & -0.81 & 0.65 & -4.561 & 0.001 & $* *$ \\
\end{tabular}

${ }^{*}=$ significant, ${ }^{* *}=$ highly significant. $\mathrm{A}=$ Clay; $\mathrm{Lf}=$ fine silt; $\mathrm{Lg}=$ coarse silt; $\mathrm{Sf}=$ Fine sand; $\mathrm{Sg}=$ coarse sand; $\mathrm{Q}=$ Quantity of organic carbon; Is = Structural stability index, $\mathrm{Pt}=$ Total porosity. 


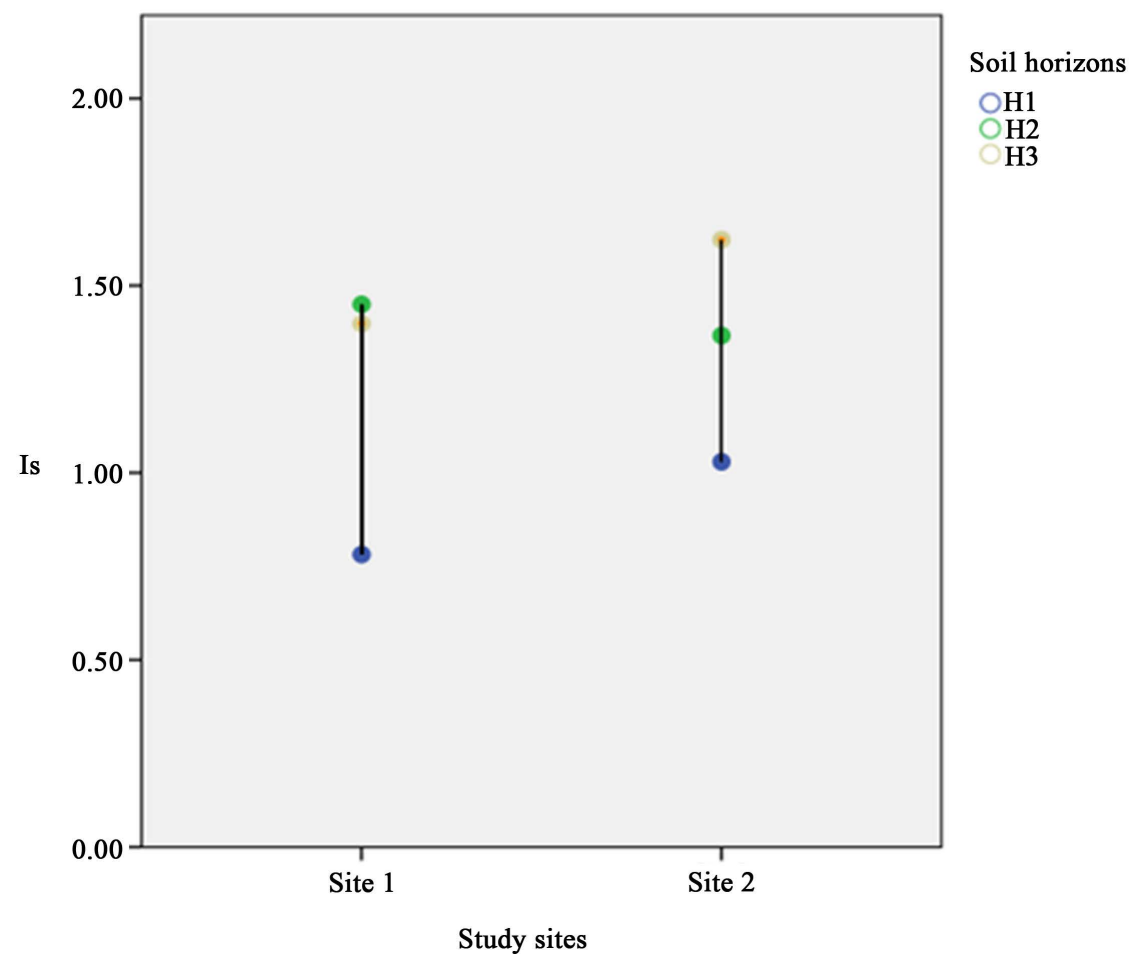

Figure 4. Evolution of the structural stability of different soils.

and positive correlations were observed between the stock of organic matter (Q) and $\mathrm{pH}$ as well as between $(\mathrm{Q})$ and Sf. The correlation coefficients are respectively 0.72 and 0.74 . A significant and negative correlation is observed between $\mathrm{Q}$ and Is $(\mathrm{r}=-0.72)$. The structural stability index is negatively correlated with $\mathrm{pH}$ and Lf. The values of $\mathrm{r}$ are, respectively, -0.56 and -0.76 . Fine sand is positively correlated with $\mathrm{pH}(\mathrm{r}=0.61)$ and $\mathrm{Pt}(\mathrm{r}=0.81)$.

The different significant correlations observed between the different parameters evaluated at site 2 are located between the organic matter stock $(\mathrm{Q})$ and the structural stability index on the one hand $(\mathrm{r}=-0.78)$ and on the other hand fine silt $(\mathrm{r}=-0.76)$. The pairs of variables Lf-Is and A-pH have respectively the correlation coefficient $\mathrm{r}=0.70$ and $\mathrm{r}=-0.81$.

\section{Discussion}

The morphological descriptions made at the level of the different soils indicate that the Mahana soils are of the Eutric Cambisol type. Indeed, the soils observed are very provided with coarse elements, essentially ferruginized concretions and nodules, coated, by a cortex of organic matter, which confer the particular brown color as it could be shown in the previous works of [13] on the Cambisols of Kanhankro and Anikro in the Toumodi region, in the south-central region of Côte d'Ivoire. At Sanankoro, the soils show very little vertical differentiation. The development of the macrostructure and the color vary very gradually with depth. At the surface, the macrostructure is composed of slightly sharp polyhedral aggregates of medium size $(1$ to $10 \mathrm{~cm}$ ) which flow into smaller sub-angular 
to rounded aggregates $(<1 \mathrm{~cm})$. These are composed of rounded microaggregates, of size $<1 \mathrm{~mm}$. The surface color is brown due to the presence of organic matter. In depth, while the microstructure is more and more represented, the macrostructure is less and less clear, to end up being absent from $100 \mathrm{~cm}$ deep. The color varies from yellowish red to deep red. This type of property is characteristic of Ferralsols [14].

The stability index evaluated on the different sites certainly does not contain any significant difference, even if the surface horizon of the Mahana site (Is = 0.78 ) is more stable than that of the Sanankoro site (Is = 1.08). At the level of the median horizons and at depth, the stability is poor (Is varies from 1.03 to 1.62). We note that the surface horizons are considered to be moderately stable, while those from $20 \mathrm{~cm}$ in depth have poor stability. Correlation tests carried out between the different soil parameters indicate that at site 1 the correlation coefficient obtained between $\mathrm{Q}$ and Is is significantly negative $(\mathrm{r}=-0.72)$. The same is true at site 2 where $r=-0.78$. The negative correlations obtained can be explained by the fact that the quantities of organic carbon evaluated in the various soils are relatively small. Indeed, according to [15], the organic carbon content is a major explanatory factor for structural stability. Several studies have shown a close relationship between the stability of the structure and the nature and characteristics of organic matter [16] [17]. As soon as the latter is supplied in different forms of residue, a significant improvement in structural stability is detected from the first week and develops over the following year.

All fractions of organic matter play an aggregating role: the particulate fraction [18], polysaccharides, humic substances (fulvic acids and humic acids) and microbial biomass. They act on the stability of aggregates, essentially, by two mechanisms. The first concerns the formation of micro-aggregates by the binding of mineral particles with humic substances or by the entanglement of particles with roots and mycelial hyphae. The second relates to the decrease in wettability which attenuates the intensity of the destruction of the aggregates during their humidification [19]. In addition, agricultural soil is a building constructed from aggregates of different sizes which result from the assembly of organic particles. These aggregates create a pore space between them which plays a decisive role in the circulation of water and air, even the storage and availability of nutrients [5]. The nature and intensity of the connections between the different particles on the one hand, and between the different aggregates on the other, give the architecture of the soil more or less resistance when it is subjected to external stresses such as cultural practices [4] [20]. Cultivation is generally accompanied by a decrease in the stability of the structural soil structure. These negative correlations could also be due to the nature of the clays that form there. Indeed, they induce high water constants and consequently low reserves of useful water. Clay provides physical protection for organic compounds when these are adsorbed or located in the pores of the mineral fraction, especially at the Cambisols level [21]. 


\section{Conclusions}

The results of this study show the undeniable interest of estimating the structural stability and the accumulation of organic matter in soils under long-lived cashew orchard because this plant now plays an important role both socially and economically Côte d'Ivoire.

In the light of the results obtained, the surface horizon of Cambisol (site 1) is more stable (Is $=0.78)$ than that of Ferralsol (site 2; Is $=1.08$ ) with nevertheless relatively small thicknesses. The median and depth horizons indicate poor stability (Is vary from 1.03 to 1.62). In terms of the amount of organic carbon, the values estimated at the Mahana level (site 1) vary from 1.96 to $4.53 \mathrm{t} \cdot \mathrm{ha}^{-1}$ for Cambisol (site 1) and from 1.44 to $3.46 \mathrm{t} \cdot \mathrm{ha}^{-1}$ for Ferralsol (site 2). These values remain relatively low, especially at the level of the median horizons and those at depth. Thus, the different organic matter contents are mainly linked to the method of occupying the soil under cashew orchards. The stability of the two types of soil seems to be independent of the amount of organic carbon in the different horizons. Statistical tests have shown a very highly significant but negative association between the structural stability of soils and the amount of organic carbon in the different horizons.

At the scale of the cropping system and with a view to building new technical routes, account must be taken of the relationship which exists between: 1) structural stability and the amount of organic carbon on the one hand and on the other part 2) between structural stability and water erosion of soils under cashew orchards established over a period of at least 10 years in order to improve the physical quality of the soils. Finally, it should be noted, however, that better structural stability of these soils not only causes slowing down of the phenomena of degradation of agricultural land, but reduces the decomposition of the organic matter which is protected in the aggregates. A process that further promotes the sequestration of organic carbon in soils and thus ratifies the sink function towards greenhouse gases.

\section{Conflicts of Interest}

The authors declare no conflicts of interest regarding the publication of this paper.

\section{References}

[1] Djaha, A.J.B. (2018) Contribution à l'étude des conditions optimales de production de plants greffés d'anacardier (Anacardium occidentale L., Anacardiaceae) en Côte d'Ivoire. Thèse de Doctorat Unique de Physiologie Végétale, Spécialité: Agrophysiologie et Phytopathologie, Université Félix Houphouët-Boigny, Abidjan, $104 \mathrm{p}$.

[2] Ruf, F., Kone, S. and Bebo, B. (2019) Le boom de l'anacarde en Côte d'Ivoire: Transition écologique et sociale des systèmes à base de coton et de cacao. Cahier Agriculture, 28, 21. https://doi.org/10.1051/cagri/2019019

[3] Koffi, S.Y. and Oura, K.R. (2019) Les facteurs de l'adoption de l'anacarde dans le 
bassin cotonnier de Côte d'Ivoire. Cahiers Agricultures, 28, 24.

https://doi.org/10.1051/cagri/2019025

[4] Ouattara, B., Ouattara, K., Lompo, F., Yao-Kouamé, A. and Sédogo, M.P. (2011) De la culture itinérante à la culture permanente: Impact sur le statut organique et l'agrégation d'un sol ferrique à l'Ouest du Burkina Faso. Agronomie Africaine, 23, 1-9. https://www.ajol.info/index.php/aga/article/view/73133/68940

[5] Ouattara, K., Ouattara, B., Nyberg, G., Sédogo, M.P. and Malmer, A. (2007) Ploughing Frequency and Compost Application Effects on Soil Infiltrability in a CottonMaize (Gossypium hirsutum-Zea mays L.) Rotation System on a Ferric Luvisol and a Ferric Lixisol in Burkina Faso. Soil and Tillage Research, 95, 288-297. https://doi.org/10.1016/j.still.2007.01.008

[6] Barthés, B. and Roose, E. (2001) La stabilité de l'agrégation, un indicateur de la sensibilité des sols au ruissellement et à l'érosion: Validation à plusieurs échelles. Cahiers Agricultures, 10, 185-193.

https://revues.cirad.fr/index.php/cahiers-agricultures/article/view/30296

[7] Roger-Estrade, J., Labreuche, J. and Richard, G. (2011) Effets de l'adoption des techniques culturales sans labour (TCSL) sur l'état physique des sols: Conséquences sur la protection contre l'érosion hydrique en milieu tempéré. Cahiers Agricultures, 20, 186-193. https://doi.org/10.1684/agr.2011.0490

[8] Saroa, G.S. and Lal, R. (2003) Soil Restorative Effects of Mulching on Aggregation and Carbon Sequestration in a Miamian Soil in Central Ohio. Land Degradation \& Development, 14, 481-493. https://doi.org/10.1002/ldr.569

[9] Koffi, F.K., Théophile, L., De Dreuzy, J.R., Akaffou, A.G., Bour, O. and Davy, P. (2010) Contribution d'un modèle hydrogéologique à fractures discrètes à l'étude des aquifères fracturés du socle Archéen de Touba (Nord-Ouest, Côte d'Ivoire). Journal of Water Science, 23, 41-56. https://doi.org/10.7202/038924ar

[10] Walkley, A. and Black, I.A. (1934) An Examination of the Degtjareff Method for Determining Soil Organic Matter and a Proposed Modification of the Chromic Acid Titration Method. Soil Science, 37, 29-38. https://doi.org/10.1097/00010694-193401000-00003

[11] Evans, J., Fernandez, I.J., Rustad, L.E. and Norton, S.A. (2001) Methods for Evaluating Fractions in Forest Soil. Technical Bulletin, 178, 34-45.

[12] Kemper, W.D. and Rosenau, R.C. (1986) Aggregate Stability and Size Distribution. In: Klute, A., Ed., Methods of Soil Analysis, Part 1: Physical and Mineralogical Methods, Monograph No 9, American Society of Agronomy, Madison, 425-442. https://doi.org/10.2136/sssabookser5.1.2ed.c17

[13] Yoboué, K.E., Kouadio, K.P., Blé, L.O. and Yao-Kouamé, A. (2018) Caractéristiques Morphopédologiques et Géochimiques des Sols Brunifiés de Anikro et de Kahankro (Centre-Sud de la Côte d'Ivoire). European Scientific Journal, 14, 281-300. https://doi.org/10.19044/esj.2018.v14n3p281

[14] Balbino, L.C., Bruand, A., Brossard, M., Grimaldi, M., Hajnos, M. and Guimarães, M.d.F. (2002) Changes in Porosity and Microaggregation in Clayey Ferralsols of Brazilian Cerrado on Clearing for Pasture. European Journal of Soil Science, 53, 219-230. https://doi.org/10.1046/j.1365-2389.2002.00446.x

[15] Chenu, C., Abiven, S., Annabi, M., Barray, S., Bertrand, M., Bureau, F., Cosentino, D., Darbboux, F., Duval, O., Fourrié, L., Francou, C., Houot, S., Jolivet, C., Laval, K., Le Bissonais, Y., Lemée, L., Menasseri, S., Pétraud, J.P. and Verbèque, B. (2011) Mise au point d'outils de prévision de l'évolution de la stabilité de la structure de sols sous l'effet de la gestion organique des sols. Etude et Gestion des Sols, 18, 
161-174.

[16] Annabi, M., Houot, H., Francou, F., Poitrenaud, M. and Le Bissonnais, Y. (2007) Soil Aggregate Stability Improvement with Urban Composts of Different Maturities. Soil Science Society of America Journal, 71, 413-423. https://doi.org/10.2136/sssaj2006.0161

[17] Ashagrie, Y., Zech, W., Guggenberger, G. and Mamo, T. (2007) Soil Aggregation and Total and Particulate Organic Matter Following Conversion of Native Forests to Continuous Cultivation in Ethiopia. Soil and Tillage Research, 94, 101-108. https://doi.org/10.1016/j.still.2006.07.005

[18] Six, J., Bossuyt, H., Degryze, S. and Denef, K. (2004) A History on the Link between (Micro)aggregates, Soil Biota, and Soil Organic Matter Dynamics. Soil \& Tillage Resarch, 79, 7-31. https://doi.org/10.1016/j.still.2004.03.008

[19] Chenu, C., Le Bissonnais, Y. and Arrouays, D. (2000) Organic Matter Influence on Clay Wettability and Soil Aggregate Stability. Soil Science Society of America Journal, 64, 1479-1486. https://doi.org/10.2136/sssaj2000.6441479x

[20] Ouattara, B., Ouattara, K., Coulibaly, P.J.A, Lompo, F., Yao-Kouamé, A. and Sédogo M.P. (2017) Déterminisme de la stabilité structurale des sols cultivés de la zone cotonnière ouest du Burkina Faso. African Crop Science Journal, 25, 277-290. https://doi.org/10.4314/acsj.v25i3.2

[21] Pallo, F.J.P., Sawadogo, N., Sawadogo, L., Sedogo, M.P. and Assa, A. (2008) Statut de la matière organique des sols dans la zone sudsoudanienne au Burkina Faso. Biotechnology, Agronomy, Society and Environment, 12, 291-301. https://popups.uliege.be:443/1780-4507/index.php?id=2791 